\title{
Peningkatan Ketahanan Keluarga melalui Optimalisasi Pola Asuh Maternalistik dalam Pencegahan Kejadian Pedofilia*
}

\author{
Trini Handayani**
}

\begin{abstract}
Abstrak
Peningkatan kasus kekerasan seksual pada anak (pedofilia) merupakan permasalahan dalam perlindungan anak. Pada beberapa kasus pedofilia yang terungkap, pelaku pedofilia mengalami pola asuh keluarga yang menyimpang. Artikel ini mengungkap fakta-fakta kasus pedofilia di Indonesia, dampak dan persoalan hukumnya, serta peran keluarga melalui pola asuh sebagai upaya pencegahan. Pengetahuan tentang ragam kekerasan pada anak menjadi penting bagi masyarakat dan penegak hukum. Pola asuh maternalistik diharapkan juga dapat membantu mengurangi kasus pedofilia dan mencegah munculnya pedofil baru. Pencegahan terhadap kasus pedofilia dimulai dari keluarga dengan mengoptimalkan pola asuh oleh ibu atau pengganti ibu dalam keluarga sehingga anak mengetahui dan dapat menolong dirinya sendiri apabila ada kasus yang menimpa dirinya.
\end{abstract}

Kata kunci: kekerasan seksual, maternalistik, pedofilia, perlindungan anak, pola asuh.

\section{Improvement of Family Security by Optimization of Maternalistic Parenting to Prevent Pedophilia}

\begin{abstract}
The increased numbers in sexual abuse to the children (pedophilia) has become a problems in child protection. In several convicted cases, it turned out that pedophiles experienced deviated parenting system. This article uncovers the facts of pedophilia cases in Indonesia, its impact, legal matters, and parents role in parenting system as an effort to prevent pedophilia. The general knowledge regarding the types of child abuse has also become important for both the society and law enforcement officers. In other hand, maternalistic parenting system is expected to help prevent any new pedophilia cases as well as preventing new pedophilia. The prevention of pedophilia cases began from the family by optimizing the role of mother or mother figure in a family to make sure that children have the knowledge on pedophilia and how to protect themselves from such cases.
\end{abstract}

Keywords: sexual violence, maternalistic, pedophilia, child protection, parenting.

\section{A. Pendahuluan}

Hak asasi anak merupakan bagian dari hak asasi manusia yang termuat dalam Undang-Undang Dasar 1945 (UUD 1945), dan ketentuan Konvensi Hak Anak

PADJADJARAN Jurnal IImu Hukum Volume 3 Nomor 3 Tahun 2016 [ISSN 2460-1543] [e-ISSN 2442-9325]

\footnotetext{
Artikel merupakan hasil penelitian yang termasuk dalam jenis penelitian kualitatif. Tujuan dari penelitian ini adalah mengungkap fakta, keadaan, fenomena, dan keadaan yang terjadi saat penelitian berjalan dan menyuguhkan apa adanya.

** Dosen Fakultas Hukum Universitas Suryakancana, Jl. Pasir Gede Raya-Cianjur, trinihandayani359@gmail.com, dr. (Universitas Sebelas Maret-Solo), S.H., M.H. (Universitas Suryakancana), Dr. (Universitas Islam Bandung).
} 
(Convention on the Rights of the Child) yang diratifikasi oleh pemerintah Indonesia melalui Keputusan Presiden Nomor 36 Tahun 1990 tentang Pengesahan Convention on the Rights of the Child, kemudian juga dituangkan dalam Undang-Undang Nomor 4 Tahun 1979 tentang Kesejahteraan Anak dan Undang-Undang Nomor 23 Tahun 2002 jo. Undang-Undang Nomor 35 Tahun 2014 tentang Perlindungan Anak (UU Perlindungan Anak) yang kesemuanya mengemukakan prinsip-prinsip umum perlindungan anak, yaitu non-diskriminasi, kepentingan terbaik bagi anak, kelangsungan hidup dan tumbuh kembang, dan menghargai partisipasi anak. ${ }^{1}$

Peningkatan kasus kekerasan anak yang terjadi di Indonesia dianggap sebagai salah satu indikator buruknya kualitas perlindungan anak. Keberadaan anak yang belum mampu untuk hidup mandiri tentunya sangat membutuhkan orang-orang sebagai tempat berlindung. Pertanyaan yang sering dilontarkan adalah sejauh mana pemerintah telah berupaya memberikan perlindungan (hukum) pada anak sehingga anak dapat memperoleh jaminan atas kelangsungan hidup dan penghidupannya sebagai bagian dari hak asasi manusia. Padahal, berdasarkan Pasal 20 UU Perlindungan Anak, yang berkewajiban dan bertanggungjawab terhadap penyelenggaraan perlindungan anak adalah negara, pemerintah, masyarakat, keluarga, dan orang tua. ${ }^{2}$

Laporan kasus kekerasan seksual yang dihimpun oleh Komisi Nasional Perlindungan Anak (Komnas Anak) dalam 3 tahun terakhir terus meningkat, dari jumlah tersebut, menurut jenisnya, kekerasan seksual merupakan salah satu jenis kekerasan yang mendominasi kasus kekerasan pada anak. Data Komisi Perlindungan Anak Indonesia (KPAI) mencatat kekerasan seksual terhadap anak dari Tahun 2012 sampai 2013 meningkat sebesar 30 (tiga puluh) persen dan selama 3 (tiga) tahun terakhir, rata-rata lebih dari 45 (empat puluh lima) anak mengalami kekerasan seksual setiap bulannya. Jenis kekerasan seksual yang dialami anak yang paling banyak terjadi dalam bentuk sodomi, pemerkosaan, pencabulan, serta incest. ${ }^{3}$

Pada tahun 1996, ada peristiwa Robot Gedek yang melakukan pembunuhan dan sodomi pada delapan anak jalanan. Masa kecil Robot Gedek, yang bernama asli Siswanto, sering mendapatkan serangan fisik dan serangan seksual dari orang dewasa, diperkosa dan disodomi secara brutal. Kasus lainnya adalah Baekuni, seorang pria yang dipanggil dengan sebutan Babe. Babe adalah anak seorang petani miskin di daerah Magelang, Jawa Tengah yang lahir pada tahun 1961. Pada waktu kecil, Babe merupakan anak yang kurang pintar sehingga sering tidak naik kelas. Hal ini yang membuat orang tuanya sering melakukan kekerasan fisik maupun verbal.

Nur Hidayati, Perlindungan Anak terhadap Kejahatan Kekerasan Seksual (Pedofilia), Ragam Jurnal Pengembangan Humaniora, Volume-14, Nomor-1, April 2014, hlm. 69.

Vina Kartikasari, "Tinjauan Yuridis Tentang Urgensi Perlindungan Hukum Terhadap Anak Sebagai Korban Tindak Pidana Perkosaan", Skripsi, Universitas Brawijaya, 2013, hlm. 8.

Data Komisi Perlindungan Anak Indonesia. 
Ada pula kasus dua orang petugas cleaning service di Taman Kanak-Kanak Jakarta International School (JIS) terbukti melakukan kekerasan seksual terhadap salah satu siswa yang masih berusia 5 tahun, di toilet sekolah. Kasus tersebut kemudian memicu terbongkarnya kasus-kasus kekerasan seksual lain pada anak di bawah umur diantaranya adalah kasus pencabulan oleh kakek pedofil Abah Aman di Sumedang, yang diduga mencabuli sembilan murid SD di Dusun Cipanteuneun. Kasus yang menghebohkan datang dari Sukabumi Jawa Barat, kepolisian Resor Sukabumi Kota menangkap seorang pemuda bernama Andri Sobari alias Emon, dugaan kekerasan seksual berupa pencabulan dan sodomi terhadap puluhan bocah laki-laki. Korban yang melapor ke Kantor Polres Sukabumi Kota sudah mencapai 120 orang.

Kasus kekerasan seksual yang dilakukan Robot Gedek ataupun Babe, diawali dengan penyimpangan dalam pola asuh semasa anak-anak. Pengalaman inilah yang membekas dalam ingatan kedua pedofil ini dan diimplementasi dalam bentuk kekerasan seksual pada anak. Sedangkan kasus Emon terjadi karena kehilangan figur seorang ayah setelah ayahnya meninggal dunia, ini berkaitan juga dengan kurang optimalnya pola asuh keluarga karena kehilangan kepala keluarga. Laporan Tim ESKA Surabaya (Eksploitasi Seksual Komersial Anak 2009), bahwa anak-anak yang dilacurkan di kota Surabaya, sebagian besar berasal dari keluarga miskin (38\%), selanjutnya berasal dari keluarga broken home (23\%) dan berasal dari keluarga pada umumnya sebanyak 6\%. Studi tersebut menunjukkan bahwa alasan kemiskinan (ekonomi) dan bujuk rayu calo (sosial) menjadi penyebab utama anak-anak terlibat dalam dunia pelacuran. ${ }^{4}$ Semua hal ini membuktikan bahwa pola asuh orang tua pada masyarakat miskin mempengaruhi masa depan anak.

Perlu langkah-langkah afirmatif untuk perlindungan anak sebagai kelompok yang lemah dan rentan. Orang tua merupakan ujung tombak perlindungan anak sebagaimana tercantum dalam Undang-Undang Nomor 39 Tahun 1999 tentang Hak Asasi Manusia (UU HAM) Pasal 26 ayat (2) yang berbunyi “orang tua mempunyai hak pertama untuk memilih jenis pendidikan yang akan diberikan pada anaknya, artinya bahwa orang tua yang memutuskan tentang informasi maupun pendidikan yang terbaik bagi anak-anaknya", hal ini sejalan dengan UU Perlindungan Anak Pasal 10 yang menyatakan bahwa setiap anak berhak menyatakan dan didengar pendapatnya, menerima, mencari, dan memberikan informasi sesuai dengan tingkat kecerdasan dan usianya demi pengembangan dirinya sesuai dengan nilainilai kesusilaan dan kepatutan.

Mendidik anak pada hakekatnya merupakan usaha nyata dari pihak orang tua untuk mengembangkan totalitas potensi yang ada pada diri anak. Masa depan anak

Yanuar Farida Wismayanti, Perdagangan anak perempuan yang dilacurkan: Potret Suram Kemiskinan versus Perlindungan Anak/Female Child Sex Trafficking: Gloomy Portrayal of Poverty Versus Child Protection. HIm. 93. 
di kemudian hari akan sangat tergantung dari pengalaman yang didapatkan anak termasuk faktor pendidikan dan pola asuh orang tua. Saat ini tidak sedikit orang tua yang mengejar kepentingan mereka sendiri dengan dalih untuk kesejahteraan anak, sehingga terkadang peran mereka sebagai orangtua yaitu mendidik dan mengasuh anak terabaikan. ${ }^{5}$ Merupakan suatu keyakinan bahwa kesejahteraan rakyat merupakan tanggung jawab masyarakat dan tanggung jawab tersebut dapat terwujud melalui pemerintahan. ${ }^{6}$ Namun demikian, orang tua dapat menjadi pintu pertama dalam mewujudkan kesejahteraan tersebut.

Adanya UU Perlindungan Anak tidak serta merta menurunkan fenomena kekerasan seksual yang terjadi. Anak tidak melakukan pelaporan kasus kekerasan seksual yang menimpanya karena alasan takut dan malu sehingga kemungkinan masih banyaknya kekerasan seksual yang tidak tercatat. Pemerintah dianggap kurang melakukan sosialisasi tentang pentingnya melaporkan kasus kekerasan seksual yang dialami oleh anak menyebabkan ketidaktahuan anak maupun orang tua untuk melakukan pelaporan. Selain itu, orang tua merasa malu untuk melaporkan kejadian tersebut, karena sebagian orang tua menganggap bahwa kasus kekerasan seksual yang dialami keluarganya merupakan hal yang 'tabu' dan tidak boleh diketahui oleh masyarakat. Masyarakat dan para penegak hukum juga belum memiliki pemahaman yang komprehensif terhadap pengertian dan tindakan-tindakan seperti apa yang dikatakan sebagai kekerasan terhadap anak.

Tulisan ini menjelaskan mengenai upaya pencegahan tindak kekerasan pada anak melalui pola asuh keluarga, sekaligus menunjukkan potret keadaan di masyarakat mengenai kasus-kasus kekerasan pada anak. Selain itu dalam tulisan ini juga akan dikemukakan mengenai jenis-jenis tindakan yang dapat dikatakan sebagai kekerasan pada anak dari pendekatan ilmiah. Hal ini bertujuan untuk memberi pemahaman lebih pada masyarakat khususnya para penegak hukum.

Tulisan ini merupakan sari dari penelitian kualitatif dengan metode yang deskriptif analitis. Penulis mengungkap fakta, keadaan, dan fenomena, yang terjadi di masyarakat kemudian menghubungkannya dengan ketentuan hukum yang ada. Setelah memotret kondisi dari perkara-perkara pedofilia yang terjadi di Indonesia, tulisan ini menganalisa situasi dan sikap serta pandangan yang terjadi di dalam masyarakat dengan ketentuan hukumnya.

\footnotetext{
Joko Tri Suharsono, Aris Fitriyan, Arif Setyo Upoyo, "Hubungan Pola Asuh Orang Tua terhadap Kemampuan Sosialisasi Pada Anak Prasekolah di TK Pertiwi Purwokerto Utara", Jurnal Keperawatan Soedirman (The Soedirman Journal of Nursing), Volume 4, Nomor 3, November 2009, hlm. 1.

6 Bagir Manan, Susi Dwi Harijanti, "Saat Rakyat Bicara: Demokrasi dan Kesejahteraan”, Padjadjaran Jurnal IImu Hukum, Volume 1, Nomor 1, Tahun 2014, hlm. 1.
} 


\section{B. Pengertian Anak, Pedofilia, dan Ragam Kekerasan Seksual}

Pengertian anak dalam Pasal 1 ayat (1) UU Perlindungan Anak, "anak adalah seseorang yang belum berusia 18 (delapan belas) tahun, termasuk anak yang masih dalam kandungan". Pada usia anak ini mereka rawan mendapat perlakuan buruk atau kekerasan (child abuse). Child abuse menurut organisasi kesehatan dunia (World Health Organization/WHO), adalah seluruh bentuk perlakuan buruk, baik secara fisik, emosional dan/atau seksual, penelantaran atau perlakuan lalai maupun eksploitasi terhadap anak.

Kekerasan pada anak ini dapat muncul dari seorang pedofil. Pedofil adalah pelaku pedofilia yaitu orang yang memiliki ketertarikan seksual orang dewasa terhadap anak. Anak yang menjadi sasaran pemuasan nafsu birahi pengidap pedofilia biasanya adalah anak-anak prapubertas, yaitu anak laki-laki belum mengalami mimpi basah dan bagi anak perempuan belum mendapat menstruasi. Menurut Adrianus E. Meliala, ada beberapa kategori pedophilia, yaitu mereka yang tertarik dengan anak berusia di bawah 5 tahun disebut infantophilia. Sementara itu, mereka yang tertarik dengan anak perempuan berusia 13-16 tahun disebut hebophilia, mereka yang tertarik dengan anak laki-laki di usia tersebut, dikenal dengan ephebohiles. Berdasarkan perilaku, ada yang disebut exhibitionism yaitu mereka yang suka memamerkan, menelanjangi anak, atau disebut voyeurism yaitu suka masturbasi depan anak, atau sekadar menyentuh kemaluan anak.

Pedophilia bisa karena memang kelainan, artinya orang ini (pelaku) mungkin saja pernah mengalami trauma yang sama, sehingga mengakibatkan perilaku yang menyimpang, bisa juga karena gaya hidup, seperti kebiasaan menonton pornografi, sehingga membentuk hasrat untuk melakukan hubungan seksual. Psikolog forensik Reza Indragiri Amriel menjelaskan tak semua kekerasan seksual pada anak dilakukan orang dewasa yang memiliki orientasi seksual pada anak, tetapi bisa juga terjadi dengan pelakunya orang dewasa normal. Kedua macam orang itu bisa digolongkan pedofilia selama melakukan hubungan seksual dengan anak. Tipe pertama adalah pedofilia eksklusif yaitu hanya memiliki ketertarikan pada anak. Tipe kedua adalah pedophilia fakultatif yaitu memiliki orientasi heteroseksual pada orang dewasa, tetapi tidak menemukan penyalurannya sehingga memilih anak sebagai substitusi.

Kekerasan seksual yang dilakukan di bawah kekerasan dan diikuti ancaman, sehingga korban tak berdaya itu disebut molester. Kondisi itu menyebabkan korban terdominasi dan mengalami kesulitan untuk mengungkapnya. Namun demikan, tak sedikit pula pelaku kekerasan seksual pada anak ini melakukan aksinya tanpa kekerasan, tetapi dengan menggunakan manipulasi psikologi. Anak ditipu, sehingga mengikuti keinginannya. Anak sebagai individu yang belum mencapai taraf 
kedewasaan, belum mampu menilai sesuatu sebagai tipu daya atau bukan.

Kekerasan seksual terhadap anak dapat dilihat dari sudut pandang biologis dan sosial, yang kesemuanya berkaitan dengan dampak psikologis pada anak. Secara biologis, sebelum pubertas, organ-organ vital anak tidak disiapkan untuk melakukan hubungan intim, apalagi untuk organ yang memang tidak ditujukan untuk hubungan intim. Jika dipaksakan, maka tindakan tersebut akan merusak jaringan. Ketika terjadi kerusakan secara fisik, maka telah terjadi tindak kekerasan. Sedangkan dari sudut pandang sosial, karena dorongan seksual dilampiaskan secara sembunyi-sembunyi, tentu saja pelaku tidak ingin diketahui oleh orang lain. Pelaku akan berusaha membuat anak yang menjadi sasaran 'tutup mulut'. Salah satu cara yang paling mungkin dilakukan adalah dengan melakukan intimidasi. ${ }^{8}$

Dalam rangka memahami masalah kekerasan dan penyimpangan seksual, perlu diketahui tentang fase pskoseksual pada manusia. Secara teori setiap manusia memiliki fase psikoseksual, menurut Sigmund Freud fase terebut adalah: 1. Fase oral; 2. Fase Anal; 3. Fase Falik; 4. Fase Latent; dan 5. Fase Genital. Pada fase oral, terdapat kesenangan dari rangsangan oral melalui kegiatan memuaskan seperti mencicipi dan mengisap, konflik terjadi tatkala terjadi proses penyapihan. Fiksasi oral dapat menyebabkan terjadinya masalah yang berkaitan dengan minum, merokok, makan ataupun menggigit-gigit kuku. Pada fase anal, fokus utama dari libido adalah pengendalian kandung kemih dan buang air besar, keberhasilan pada tahap ini tergantung orang tua dalam melakukan pendekatan pelatihan toilet. Pada fase Falik, fokus utama dari libido adalah alat kelamin. Pada fase ini, usia anak berkisar 3-6 tahun sudah mulai paham tentang perbedaan jenis kelamin laki-laki dan perempuan. Freud percaya bahwa anak laki-laki menjadikan ayahnya sebagai saingan kasih sayang ibu, pada fase ini, anak perempuan mulai meniru perbuatan yang dilakukan ibunya dan sebaliknya, anak laki-laki melakukan perbuatan dengan meniru perilaku ayahnya. Selanjutnya adalah fase latent, usia (6-12) tahun, aktivitas seksual pada masa ini cenderung tidak nampak. Hal ini terjadi karena individu sedang disibukkan dengan pencarian prestasi. Terakhir adalah fase genital yang terjadi pada usia lebih dari 12 tahun, merupakan fase akhir dari keseluruhan fase yang ada, pada fase ini, muncul kembali aktivitas seksual manusia.

Lebih lanjut Freud menjelaskan, sebagian besar kepribadian dibentuk pada usia 5 (lima) tahun. Awal perkembangan berpengaruh besar dalam pembentukan kepribadian dan terus mempengaruhi perilaku di kemudian hari. Jika tahap-tahap psikoseksual selesai dengan sukses, hasilnya adalah kepribadian yang sehat. Jika masalah tertentu tidak dapat diselesaikan pada tahap yang tepat, maka hingga konflik tersebut diselesaikan, individu akan tetap 'terjebak' dalam tahap ini. Hal inilah yang menjadi pemicu tidakan seksual yang menyimpang.

Ivo Noviana, Kekerasan Seksual Terhadap Anak: Dampak Dan Penanganannya, Sosio Informa, Volume 1, Nomor 1, Januari - April, Tahun 2015, hlm. 17. 
Perilaku seksual yang menyimpang sering berujung pada perbuatan kekerasan seksual. Dalam konteks anak, Ricard J. Gelles menjelaskan bahwa kekerasan terhadap anak merupakan perbuatan disengaja yang menimbulkan kerugian atau bahaya terhadap anak-anak (baik secara fisik maupun emosional). Bentuk kekerasan terhadap anak dapat diklasifikasikan menjadi kekerasan secara fisik, kekerasan secara psikologi, kekerasan secara seksual dan kekerasan secara sosial. Kekerasan seksual terhadap anak menurut End Child Prostitution in Asia Tourism (ECPAT) Internasional merupakan hubungan atau interaksi antara seorang anak dengan seorang yang lebih tua atau orang dewasa seperti orang asing, saudara sekandung atau orang tua di mana anak dipergunakan sebagai objek pemuas kebutuhan seksual pelaku. Perbuatan ini dilakukan dengan atau tanpa menggunakan paksaan, ancaman, suap, tipuan, bahkan tekanan. Bentuk-bentuk kekerasan seksual itu sendiri dapat dalam bentuk tindakan perkosaan ataupun pencabulan. ${ }^{9}$

Bentuk kekerasan seksual pada anak, antara lain perkosaan, sodomi, seks oral, sexual gesture (serangan seksual secara visual termasuk ekshibisionisme), sexual remark (serangan seksual secara verbal), pelecehan seksual, pelacuran anak, dan sunat klitoris pada anak perempuan. ${ }^{10}$ Menurut Lyness, kekerasan seksual terhadap anak, meliputi tindakan menyentuh atau mencium organ seksual anak, tindakan seksual atau pemerkosaan terhadap anak, memperlihatkan media/benda porno, menunjukkan alat kelamin pada anak dan sebagainya.

Kekerasan seksual (sexual abuse), dapat dikategorikan berdasar identitas pelaku, yaitu: ${ }^{11}$

a. Familial Abuse, contohnya adalah incest, yaitu kekerasan seksual di mana antara korban dan pelaku masih ada hubungan darah, menjadi bagian dalam keluarga inti. Termasuk seseorang yang menjadi pengganti orang tua, misalnya ayah tiri, atau kekasih, pengasuh atau orang yang dipercaya merawat anak. Mayer menyebutkan kategori incest dalam keluarga dan mengaitkan dengan kekerasan pada anak, yaitu kategori pertama, penganiayaan (sexual molestation), hal ini meliputi interaksi noncoitus, petting, fondling, exhibitionism, dan voyeurism, semua hal yang berkaitan untuk menstimulasi pelaku secara seksual. Kategori kedua, perkosaan (sexual assault), berupa oral atau hubungan dengan alat kelamin, masturbasi, stimulasi oral pada penis (fellatio), dan stimulasi oral pada klitoris (cunnilingus). Kategori terakhir yang paling fatal disebut perkosaan secara paksa (forcible rape), meliputi kontak seksual. Mayer mengatakan bahwa paling banyak ada dua kategori terakhir yang menimbulkan trauma terberat bagi anak-anak.

\footnotetext{
Ibid., hlm. 15.

Ismantoro Dwi Yuwono, Op.cit., hlm. 7.

Ivo Noviana, Op.cit., hlm. 16.
} 
b. Extra Familial Abuse. Kekerasan seksual adalah kekerasan yang dilakukan oleh orang lain di luar keluarga korban. Pada pola pelecehan seksual di luar keluarga, pelaku biasanya orang dewasa yang dikenal oleh sang anak dan telah membangun relasi dengan anak tersebut, kemudian membujuk sang anak ke dalam situasi di mana pelecehan seksual tersebut dilakukan, sering dengan memberikan imbalan tertentu yang tidak didapatkan oleh sang anak di rumahnya. Sang anak biasanya tetap diam karena bila hal tersebut diketahui mereka takut akan memicu kemarahan dari orangtua mereka. Selain itu, beberapa orangtua kadang kurang peduli tentang di mana dan dengan siapa anak-anak mereka menghabiskan waktunya. Anak-anak yang sering bolos sekolah cenderung rentan untuk mengalami kejadian ini dan harus diwaspadai.

Dalam melakukan kekerasan seksual terhadap anak, biasanya ada tahapan yang dilakukan oleh pelaku. Dalam hal ini, kemungkinan pelaku mencoba perilaku untuk mengukur kenyamanan korban. Jika korban menuruti, kekerasan akan berlanjut dan intensif, berupa: 1) Nudity (dilakukan oleh orang dewasa); 2) Disrobing (orang dewasa membuka pakaian di depan anak); 3) Genital exposure (dilakukan oleh orang dewasa); 4) Observation of the child (saat mandi, telanjang, dan saat membuang air); 5) Mencium anak yang memakai pakaian dalam; 6) Fondling (meraba-raba dada korban, alat genital, paha, dan bokong); 7) Masturbasi; 8) Fellatio (stimulasi pada penis, korban atau pelaku sendiri); 9) Cunnilingus (stimulasi pada vulva atau area vagina, pada korban atau pelaku); 10) Digital penetration (pada anus atau rectum); 11) Penile penetration (pada vagina); 12) Digital penetration (pada vagina); 13) Penile penetration (pada anus atau rectum); 14) Dry intercourse (mengelus-elus penis pelaku atau area genital lainnya, paha, atau bokong korban).

\section{Perlindungan Anak}

Dalam ketentuan Pasal 34 UUD 1945, negara mempunyai kewajiban untuk melindungi harkat dan martabat anak, ketentuan ini berimplikasi terhadap keharusan negara dalam memberikan perlindungan yang maksimal terhadap anak. Berbagai macam persoalan anak, menurut kesepakatan beberapa negara, ditata dalam suatu wadah yang disebut UNICEF (United International Children Educational of Fund). Anak dikelompokkan sebagai kelompok rentan selain orang yang berusia lanjut, fakir miskin, wanita hamil dan penyandang cacat, ini sejalan dengan UU HAM Pasal 5 ayat (3) yang menyebutkan bahwa kelompok rentan adalah orang usia lanjut, anak-anak, fakir miskin, wanita hamil dan penyandang cacat.

Perlindungan anak adalah segala kegiatan untuk menjamin dan melindungi anak dan hak-haknya agar dapat hidup, tumbuh, berkembang dan berpartisipasi secara optimal sesuai dengan harkat dan martabat kemanusiaan serta mendapat 
perlindungan dari kekerasan dan diskriminasi demi terwujudnya anak Indonesia yang berkualitas, berakhlak mulia dan sejahtera. ${ }^{12}$

Kemunculan UU Perlindungan Anak menjadi secercah cahaya untuk mengurangi terjadinya kekerasan terhadap anak. Dalam Pasal 3 UU Perlindungan Anak mengandung aspek penting diantaranya yaitu perlindungan anak dari kekerasan dan diskriminasi serta terwujudnya anak yang berkualitas, berakhlak mulia dan sejahtera. Sedangkan prinsip dasar konvensi hak-hak anak diantaranya meliputi kepentingan yang terbaik bagi anak serta hak untuk hidup, kelangsungan hidup dan perkembangan. Dalam Pasal 59 UU Perlindungan Anak, dijelaskan bahwa pemerintah dan lembaga negara lainnya berkewajiban dan bertanggung jawab untuk memberikan perlindungan khusus, diantaranya yaitu anak tereksploitasi secara ekonomi dan atau seksual, anak yang diperdagangkan serta anak korban perlakuan salah dan penelantaran. ${ }^{13}$

Khusus mengenai kekerasan seksual pada anak, KUHP di Indonesia menggunakan terminologi untuk perbuatan tersebut adalah parbuatan 'cabul'. Menurut R. Soesilo, perbuatan cabul sebagaimana tercantum dalam Pasal 289 KUHP adalah segala perbuatan yang melanggar kesusilaan (kesopanan) atau perbuatan keji yang ada kaitan dengan nafsu birahi kelamin, misalnya mencium, meraba-raba anggota kemaluan, buah dada, dan semua bentuk perbuatan cabul. Persetubuhan juga termasuk ke dalam pengertian ini. ${ }^{14}$ Apa yang dikemukakan $\mathrm{R}$. Soesilo tersebut berkaitan dengan tindakan yang bersifat sentuhan saja. Setelah mengetahi ragam kekerasan seksual pada anak sebagaimana yang telah dikemukakan pada bab sebelumnya, maka kita dapat mengetaui secara lebih luas bahwa perbuatan cabul tidak hanya berkaitan dengan yang bersentuhan saja. Mempertontonkan atau bahkan hal-hal yang bersifat verbal-pun seharusnya dapat dikatagorikan sebagai perbuatan cabul jika itu berkaitan dengan anak.

Mengenai ancaman hukumannya sendiri, dalam KUHP penerapan pasalpasalnya tergantung dari jenis dan akibat pencederaannya. Pada pencederaan anak yang bersifat seksual, pasal yang diterapkan Pasal 287 KUHP (ancaman pidana penjara paling lama 9 tahun). Pasal 290 KUHP butir 3 (ancaman pidana penjara paling lama 7 tahun). Sanksi pidana yang dikenakan terhadap pelaku kekerasan seksual cukup berat, ini dimungkinkan karena tindakan kekerasan seksual merupakan tindakan kejahatan yang tidak dapat ditolerir. Hal ini karena buruknya dampak tindakan kekerasan seksual terhadap anak yang menjadi korbannya.

\footnotetext{
I Gede Arya B. Wiranata, Ed. Muladi, Hak Asasi (Anak) dalam Realitas Quo Vadis? dalam kumpulan naskah Hak Asasi Manusia (Hakekat, Konsep dan Implikasinya dalam Perspektif Hukum dan Masyarakat), Bandung: Refika Aditama, 2005, hlm. 231-233.

13 Bambang Waluyo, Victimologi Perlindungan Korban dan Saksi, Jakarta: Sinar Grafika, 2012, hlm. 70-72.

14 Ivo Noviana, Op.cit., hlm. 1-2.
} 


\section{Gambaran Kasus Tindak Kekerasan pada Anak}

Dari berbagai pemberitaan telah menunjukkan kasus kekerasan seksual terhadap anak terjadi hampir di seluruh daerah di Indonesia. Pemberitaan ini diyakini hanyalah sedikit dari kekerasan seksual terhadap anak yang merupakan fenomena gunung es. Anak yang menjadi korban kekerasan seksual (baik pemerkosaan maupun sodomi) tidak hanya mengalami gangguan fisik, maupun kerusakan organ tubuh dan seksualitasnya, serta terjangkit penyakit infeksi menular seksual, namun korban juga mengalami trauma psikologis berat sepanjang hidupnya dan dapat mengalami gangguan kejiwaan apabila tidak segera ditangani secara optimal yang akhirnya berdampak pada gangguan pertumbuhan maupun perkembangan jiwanya.

Data pelanggaran hak anak yang direkapitulasi oleh Pusat data dan Informasi (Pusdatin) Komnas Anak. Kasus anak sepanjang tahun 2013 masih didominasi oleh kasus kekerasan terhadap anak, terlebih kasus kekerasan seksual. Komnas Anak menetapkan tahun 2013 ini sebagai kondisi Darurat Nasional Kejahatan Seksual terhadap anak. Berdasarkan data kasus yang dipantau Pusdatin Komnas Anak, sepanjang tahun 2013 terdapat 1.620 kasus. Dengan rincian, kasus kekerasan fisik sebanyak 490 kasus (30\%), kekerasan psikis sebanyak 313 kasus (19\%) dan paling banyak yaitu kasus kekerasan seksual sebanyak 817 (51\%). Beberapa latar belakang kasus kekerasan seksual diantaranya karena pengaruh media pornografi sebanyak 81 kasus (8\%), terangsang dengan korban sebanyak 178 kasus (17\%), hasrat tak tersalurkan sebanyak 298 kasus (29\%), dan alasan lainnya. Anak yang mengalami kekerasan dalam bentuk apapun, cenderung akan mengalami trauma, akibat secara psikologis adalah mengalami stress psikologis berkepanjangan dan anak tersebut dapat menderita seumur hidupnya. Lebih mengkhawatirkan lagi, seorang anak yang menjadi korban kekerasan seksual memiliki 70\% kecenderungan tumbuh menjadi pelaku kekerasan seksual.

Data kasus kekerasan pada anak yang begitu tinggi ini disebabkan kurangnya pemahaman masyarakat seperti orangtua dan bahkan para penegak hukum. Dalam rangka mengetahui pemahaman orang tua terhadap pedofilia serta pencegahannya, penulis melakukan wawancara terhadap 20 orang ibu yang mempunyai anak balita. Responden mempunyai pendidikan rata-rata sarjana. Pertanyaan yang diberikan meliputi: pengertian pedofilia, tingkat perkembangan anak termasuk fase falik, pendidikan seks sejak dini, pemahaman terhadap organ tubuh terlarang serta pemahaman tentang pencegahan kejadian pedofilia.

Hasil wawancara terhadap responden tersebut, rata-rata baik (nilai 70 sampai dengan 100), kecuali pertanyaan tentang pengertian fase falik pada perkembangan anak, hanya 2 responden yang menjawab dengan benar, sisanya, 18 responden menjawab salah, ini menunjukkan bahwa orang yang berpendidikan tinggi belum sepenuhnya memahami pentingnya pendidikan seks sejak fase falik. 


\section{E. Macam-Macam Pola Asuh}

Peranan ibu dalam pola pengasuhan anak berupa sikap dan praktek pengasuhan ibu dalam kedekatannya dengan anak, merawat, cara memberi makan, serta kasih sayang. Pengasuhan anak adalah suatu fungsi penting pada berbagai kelompok sosial dan kelompok budaya. Peranan ibu dalam pola pengasuhan anak juga meliputi pemenuhan kebutuhan dasar anak seperti pemberian makan, mandi, menyediakan dan memakai pakaian buat anak, termasuk didalamnya adalah monitoring kesehatan anak, menyediakan obat, dan membawanya ke petugas kesehatan profesional. Pengasuhan anak meliputi aktivitas perawatan terkait gizi atau penyiapan makanan dan menyusui, pencegahan dan pengobatan penyakit, memandikan anak, membersihkan pakaian anak, membersihkan rumah.

Pola asuh terhadap anak merupakan hal yang sangat penting karena akan memengaruhi proses tumbuh kembang balita. Pola pengasuhan anak berkaitan erat dengan keadaan ibu terutama kesehatan, pendidikan, pengetahuan, sikap dan praktik tentang pengasuhan anak. Dalam berbagai penelitian menunjukkan bahwa kepribadian orangtua sangat menentukan pola interaksi ibu dan anak. Pengaruh struktur dan watak ibu yang mengasuh anak balita mempunyai efek yang sangat besar dalam hubungan ibu dan anak. Kerangka konseptual yang dikemukan oleh UNICEF (1997) menekankan bahwa tiga komponen makanan, kesehatan dan asuhan merupakan faktor-faktor yang berperan dalam menunjang pertumbuhan dan perkembangan anak yang optimal. ${ }^{15}$

Pengasuhan (parenting) merupakan suatu proses panjang dalam kehidupan seorang anak mulai dari masa prenatal hingga dewasa. Pengasuhan memerlukan sejumlah kemampuan interpersonal dan mempunyai tuntutan emosional yang besar, namun sangat sedikit pendidikan formal mengenai tugas ini, karena tidak ada sekolah menjadi orang tua. Pola asuh merupakan bagian dari pengasuhan yang berlaku dalam keluarga, melalui interaksi antara orang tua dengan anak selama mengadakan kegiatan pengasuhan.

Ada berbagai pola asuh yang diterapkan orang tua kepada anaknya dengan berbeda-beda. Baumrind mengidentifikasi 3 pola utama pengasuhan orang tua. Pertama, pola asuh demokratif bersifat fleksibel, tegas, adil, dan logis. Kedua, pola asuh otoriter mengharapkan kepatuhan mutlak dan melihat bahwa anak butuh untuk dikontrol. Ketiga, pola asuh permissif membolehkan anak untuk mengatur hidup mereka sendiri dengan kurangnya kontrol dari orang tua. Faktor yang mempengaruhi pola asuh diantaranya pengetahuan pendidikan, budaya, dan Lingkungan. Pengetahuan sendiri didapatkan melalui pendidikan formal. Mayoritas budaya orang tua mempelajari praktik pengasuhan dari orang tua mereka sendiri. Setelah mempunyai anak orang tua mempraktikan didikan tersebut. Sebagian

Enggal Wildan Prabowo, Ishartono dan Meilanny Budiarti, Pola Asuh Anak Oleh Ibu Usia Dini, PROSIDING KS: RISET \& PKM, Volume 3, Nomor 2, ISSN: 2442-4480, hlm. 176. 
praktik tersebut mereka terima, namun sebagian lagi mereka tinggalkan. Sayangnya, ketika metode orang tua diteruskan dari satu generasi ke generasi berikutnya, praktik yang baik maupun yang buruk diteruskan. ${ }^{16}$

Peran ayah atau 'fathering' lebih merujuk pada perannya dalam parenting. Hal ini dikarenakan fathering merupakan bagian dari Parenting. Idealnya ayah dan ibu mengambil peranan yang saling melengkapi dalam kehidupan rumah tangga dan perkawinannya, termasuk didalamnya berperan sebagai model yang lengkap bagi anak-anak dalam menjalani kehidupannya. ${ }^{17}$ Ayah memiliki peran dalam keterlibatannya dengan keluarga yaitu: ${ }^{18}$

a. Economic Provider, yaitu ayah dianggap sebagai pendukung finansial dan perlindungan bagi keluarga. Sekalipun tidak tinggal serumah dengan anak, namun ayah tetap dituntut untuk menjadi pendukung finansial;

b. Friend \& Playmate, ayah dianggap sebagai 'fun parent' serta memiliki waktu bermain yang lebih banyak dibandingkan dengan ibu. Ayah banyak berhubungan dengan anak dalam memberikan stimulasi yang bersifat fisik;

c. Caregiver, ayah dianggap sering memberikan stimulasi afeksi dalam berbagai bentuk, sehingga memberikan rasa nyaman dan penuh kehangatan;

d. Teacher \& Role Model, sebagaimana dengan ibu, ayah juga bertanggung jawab dalam terhadap apa saja yang dibutuhkan anak untuk masa mendatang melalui latihan dan teladan yang baik bagi anak;

e. Monitor and disciplinary, ayah memenuhi peranan penting dalam pengawasan terhadap anak, terutama begitu ada tanda-tanda awal penyimpangan, sehingga disiplin dapat ditegakkan;

f. Protector, ayah mengontrol dan mengorganisasi lingkungan anak, sehingga anak terbebas dari kesulitan/bahaya;

g. Advocate, ayah menjamin kesejahteraan anaknya dalam berbagai bentuk, terutama kebutuhan anak ketika berada di institusi di luar keluarganya;

h. Resource, dengan berbagai cara dan bentuk, ayah mendukung keberhasilan anak dengan memberikan dukungan di belakang layar.

\section{F. Dampak Kekerasan Seksual pada Anak}

Dampak kekerasan seksual cenderung menimbulkan efek traumatis baik pada anak maupun pada orang dewasa. Namun, kasus kekerasan seksual sering tidak terungkap karena adanya penyangkalan terhadap peristiwa kekerasan seksual yang terjadi. Lebih sulit lagi adalah jika kekerasan seksual ini terjadi pada anak-anak,

\footnotetext{
Syifa Khoirunnisa, Nita Fitria, Helwiyah Rofi, Gambaran Pola Asuh Orang Tua yang Dipersepsikan Remaja SMA Negeri Jatinangor Kabupaten Sumedang, Jurnal IImu Keperawatan. Volume III, Nomor 2, September 2015, ISSN: 2338-7246, hlm. 54.

17 Enjang Wahyuningrum, Peran Ayah (fathering) pada Pengasuhan Anak Usia Dini, Fakultas Psikologi Universitas Kristen Satya Wacana, hlm. 6.

$18 \quad$ Ibid., hlm. 7.
} 
karena anak-anak korban kekerasan seksual tidak mengerti bahwa dirinya menjadi korban. Korban sulit mempercayai orang lain sehingga merahasiakan peristiwa kekerasan seksualnya. Selain itu, anak cenderung takut melaporkan karena mereka merasa terancam akan mengalami konsekuensi yang lebih buruk bila melapor, anak merasa malu untuk menceritakan peristiwa kekerasan seksualnya, anak merasa bahwa peristiwa kekerasan seksual itu terjadi karena kesalahan dirinya dan peristiwa kekerasan seksual membuat anak merasa bahwa dirinya mempermalukan nama keluarga. Dampak pelecehan seksual yang terjadi ditandai dengan adanya powerlessness, di mana korban merasa tidak berdaya dan tersiksa ketika mengungkap peristiwa pelecehan seksual tersebut. ${ }^{19}$

Dampak yang muncul dari kekerasan seksual kemungkinan adalah depresi, fobia, dan mimpi buruk, curiga terhadap orang lain dalam waktu yang cukup lama. Ada pula yang merasa terbatasi di dalam berhubungan dengan orang lain, berhubungan seksual dan disertai dengan ketakutan akan munculnya kehamilan akibat dari perkosaan. Bagi korban perkosaan yang mengalami trauma psikologis yang sangat hebat, ada kemungkinan akan merasakan dorongan yang kuat untuk bunuh diri. $^{20}$

Finkelhor dan Browne mengkategorikan 4 (empat) jenis dampak trauma akibat kekerasan seksual yang dialami oleh anak-anak, yaitu: ${ }^{21}$

1. Pengkhianatan (Betrayal). Kepercayaan merupakan dasar utama bagi korban kekerasan seksual. Sebagai seorang anak, mempunyai kepercayaan kepada orangtua dan kepercayaan itu dimengerti dan dipahami. Namun, kepercayaan anak dan otoritas orangtua menjadi hal yang mengancam anak;

2. Trauma secara Seksual (Traumatic sexualization). Russel menemukan bahwa perempuan yang mengalami kekerasan seksual cenderung menolak hubungan seksual, dan sebagai konsekuensinya menjadi korban kekerasan seksual dalam rumah tangga. Finkelhor mencatat bahwa korban lebih memilih pasangan sesama jenis karena menganggap laki-laki tidak dapat dipercaya;

3. Merasa Tidak Berdaya (Powerlessness). Rasa takut menembus kehidupan korban. Mimpi buruk, fobia, dan kecemasan dialami oleh korban disertai dengan rasa sakit. Perasaan tidak berdaya mengakibatkan individu merasa lemah. Korban merasa dirinya tidak mampu dan kurang efektif dalam bekerja. Beberapa korban juga merasa sakit pada tubuhnya. Sebaliknya, pada korban lain memiliki intensitas dan dorongan yang berlebihan dalam dirinya;

4. Stigmatization. Korban kekerasan seksual merasa bersalah, malu, memiliki gambaran diri yang buruk. Rasa bersalah dan malu terbentuk akibat

\footnotetext{
Ivo Noviana, Op.cit., hlm. 18.

20 M. Anwar Fuadi, "Dinamika Psikologi Kekerasan Seksual: Studi Fenomenologi, Psikoislamika”, Jurnal Psikologi Islam (JPI), Volume 8, Nomor 2, Januari 2011, hIm. 194.

21 Ivo Noviana, Op.cit., hlm. 19-20.
} 
ketidakberdayaan dan merasa bahwa mereka tidak memiliki kekuatan untuk mengontrol dirinya. Anak sebagai korban sering merasa berbeda dengan orang lain, dan beberapa korban marah pada tubuhnya akibat penganiayaan yang dialami. Korban lainnya menggunakan obat-obatan dan minuman alkohol untuk menghukum tubuhnya, menumpulkan inderanya, atau berusaha menghindari memori kejadian tersebut.

Dalam konteks Indonesia, elemen yang tepat dan efektif untuk mengeliminasi kekerasan secara progresif adalah: pendidikan (education) dan pelatihan (training). Pendidikan merupakan mekanisme primer yang representatif dan efektif di masyarakat serta penting bagi generasi mendatang. Mengubah sikap, memerlukan skala waktu yang relatif lama. ${ }^{22}$

Dari berbagai fase perkembangan psikoseksual tersebut, fase Falik merupakan fase yang terpenting, karena pada fase ini sudah mulai mengenal perbedaan jenis kelamin, oleh karena itu pendidikan personal safety skills sangat tepat dilaksanakan pada fase Falik ini. Ibu merupakan orang yang bertanggung jawab terhadap pola asuh anak diberi pembekalan tentang personal safety skills pada beberapa kegiatan terstruktur di masyarakat.

Personal safety skills atau keterampilan keselamatan pribadi merupakan seperangkat keterampilan yang perlu dikuasai oleh anak agar dapat menjaga keselamatan dirinya dan terhindar dari tindakan kekerasan seksual. Personal safety skills terdiri atas 3 (tiga) komponen keterampilan yang dikenal dengan slogan 3R yakni:

a. Recognize, yakni kemampuan anak mengenali ciri-ciri orang yang berpotensi melakukan kekerasan seksual (predator). Pada komponen recognize ini, anak diajari untuk mengenali bagian-bagian tubuh pribadi yang tidak boleh disentuh sembarang orang, dan bagaimana mengatakan tidak, saat orang lain melakukan sentuhan tidak aman (unsafe touch), menyuruh membuka baju atau memperlihatkan bagian tubuh pribadi, menyuruh anak melihat bagian tubuh pribadi sang pelaku dan memperlihatkan konten seksual. Anak diberikan kesadaran atas hak-hak pribadi terhadap tubuhnya, serta bagaimana mereka boleh menentukan siapa yang boleh dan tidak boleh menyentuh bagian tubuhnya, terutama yang sensitif atau yang sangat pribadi. Dengan demikian anak diharapkan dapat membedakan pelaku tindakan kekerasan seksual daripada orang lainnya yang berkomunikasi atau melakukan kontak fisik dengannya;

b. Resist, yakni kemampuan anak bertahan dari perlakuan atau tindakan kekerasan seksual, misalnya berteriak minta tolong, memberitahu orang lain

Ariefa Efianingrum dan Mami Hajaroh, Kebijakan Pencegahan Kekerasan terhadap Anak di Sekolah Dasar, Prosiding Riset Kebijakan Pendidikan Anak di Indonesia, kerja sama antara Kemendikbud, UNICEF Indonesia, Lembaga Penelitian SMERU, 2012, hlm. 340. 
bahwa orang yang menggandengnya bukanlah ayah atau ibunya, dan sebagainya. Pada komponen resist ini anak diajari untuk mengidentifikasi sejumlah tindakan yang dapat ia lakukan ketika berhadapan dengan pelaku kekerasan seksual atau ketika berada dalam situasi yang memungkinkan terjadinya tindakan kekerasan seksual. Anak diajari untuk dapat mengabaikan rayuan dan bujukan dari orang yang berpotensi melakukan kekerasan seksual, mengatakan "Tidak!" atau "Stop!" dengan lantang dan tegas pada orang yang mencoba melakukan tindak kekerasan seksual pada mereka, melakukan tindakan perlawanan seperti memukul, menggigit, menendang pada pelaku kekerasan seksual, melarikan diri dari pelaku kekerasan seksual dan berteriak meminta pertolongan pada orang sekitar;

c. Report, yakni kemampuan anak melaporkan perilaku kurang menyenangkan secara seksual yang diterimanya dari orang dewasa, bersikap terbuka kepada orang tua agar orang tuanya dapat memantau kondisi anak tersebut. Pada komponen report anak diajari agar mampu bersikap terbuka atas tindakan kekerasan seksual yang diterimanya, dan mampu melaporkan pelaku pada orang dewasa atau lembaga lain yang berkepentingan dan dipercaya oleh anak untuk membantunya. ${ }^{23}$

Dalam masyarakat urban para orang tua memiliki tingkat pendidikan yang cukup tinggi dan sudah melek internet. Oleh karena itu, pemahaman dan pencegahan pedofilia dapat diserap secara cepat. Penyebaran sosialisasi dapat dilakukan oleh media sosial. Materi sosialisasi dapat berupa model pola asuh demokratis oleh ibu (maternal) serta pencegahan pedofilia menggunakan metode 3R. Selain itu dapat dilakukan konsultasi melalui media sosial seputar pencegahan pedofilia. Sedangkan pada masyarakat rural, pemahaman dan pencegahan pedofilia dilakukan secara terus menerus dengan sasaran ibu balita, melalui forum yang sudah ada di desa, seperti di Pos Pelayanan Terpadu (Posyandu), Bina Keluarga Balita (BKB), Pembinaan Kesejahteraan Keluarga (PKK) maupun forum religi yang sudah ada di masing-masing desa.

Sejumlah fakta empiris yang telah ada menegaskan pentingnya pelatihan keterampilan dalam rangka mengajari anak keterampilan menjaga diri dari pelaku kekerasan seksual ataupun kondisi yang memungkinkan terjadinya kekerasan seksual. Fakta-fakta tersebut seyogyanya menjadi pemicu sekaligus tantangan bagi para profesional untuk merumuskan suatu program pencegahan kekerasan seksual pada anak yang terkoordinasi dan sistematis serta fokus terhadap peningkatan keterampilan dan kemampuan anak untuk menjaga diri dari pelaku kekerasan seksual. Salah satu upaya pencegahan dapat dilakukan melalui pengajaran personal safety skills atau keterampilan keselamatan pribadi pada anak. Dalam studi meta

Esya Anesty Mashudi dan Nur'aini, Pengajaran Personal Safety Skills dalam Pencegahan Kekerasan Seksual Pada Anak, Metodik Didaktik, Volume 9, Nomor 2, Januari 2015, hlm. 66-67. 
analisis yang dilakukan Berrick and Barth (1992), diketahui bahwa pengetahuan yang diperoleh dari kelas personal safety skills ini cenderung bertahan lama dan terpelihara. ${ }^{24}$

Tindak Pidana penyimpangan seksual dipengaruhi berbagai faktor, oleh karena itu, pencegahan dilakukan secara komprehensif dan menyangkut berbagai pihak. Presiden mengeluarkan Instruksi tentang Gerakan Nasional Anti Kejahatan Seksual terhadap Anak. Gerakan Nasional Anti Kejahatan Seksual terhadap Anak (GN-AKSA) selain melibatkan unsur pemerintahan, tetapi juga melibatkan seluruh elemen masyarakat maupun dunia usaha. Gerakan ini belum terasa gaungnya sampai ke daerah-daerah, terutama daerah dengan permasalahan kekerasan seksual. Perlu revitalisasi GN-AKSA oleh pemerintah yang sekarang.

\section{G. Penutup}

Kekerasan seksual pada anak yang dilaporkan mengalami peningkatan setiap tahunnya. Penanganan dilaksanakan secara komprehensif dimulai dari keluarga untuk mencegah dan melindungi anak sebagai korban kekerasan seksual. Fathering sebagai pelengkap pola asuh orang tua dalam rumah tangga. Perannya sama dengan maternalistik parenting akan tetapi waktu yang dihabiskan bersama anak lebih sedikit dari pada dengan sosok ibu, oleh karena itu, sosok ibu merupakan orang yang tepat dalam optimalisasi pola asuh. Materi yang disampaikan meliputi model pola asuh maupun 3R, penyampaian materi disesuaikan dengan kultur masyarakat yang ada. Pola asuh maternalistik yang bersifat demokratis merupakan pola asuh yang paling optimal dalam pertumbuhan dan perkembangan anak.

Kementerian Sosial Republik Indonesia telah meluncurkan Telepon Sahabat Abak (TePSA) 1500771. Layanan pengaduan tersebut dibuka untuk umum selama 24 jam penuh. TePSA ini merupakan bagian komitmen dari pemerintah dalam mengatasi berbagai kasus kekerasan terhadap anak. Tindakan yang dilakukan pemerintah ini merupakan tindakan kuratif, tindakan setelah ada kejadian. Tindakan pencegahan merupakan tindakan yang memerlukan komitmen dari berbagai stakeholder dalam pencegahan kekerasan seksual, antara lain:

1. Materi $3 R$ bagi ibu balita di setiap desa/kelurahan, dengan metode penyampaian materi disesuaikan dengan budaya dan kultur masyarakat setempat;

2. Materi disampaikan oleh kader yang sudah terlatih untuk itu;

3. Seminar dengan materi pola asuh dan 3R;

4. Materi $3 R$ dijadikan program pemerintah di Posyandu dengan evaluasi setiap minimal 3 (tiga) bulan sekali dan dilaporkan kepada bupati secara periodik berikut kasus kekerasan seksual yang terjadi didaerahnya masing-masing.

Ibid., hlm. 60-61. 


\section{Daftar Pustaka}

\section{Buku}

Bambang Waluyo, Victimologi Perlindungan Korban dan Saksi, Sinar Grafika, Jakarta, 2012.

I Gede Arya B. Wiranata, (Ed. Muladi), Hak Asasi (Anak) dalam Realitas Quo Vadis? dalam kumpulan naskah Hak Asasi Manusia (Hakekat, Konsep dan Implikasinya dalam Perspektif Hukum dan Masyarakat), Refika Aditama, Bandung, 2005.

\section{Dokumen Lain}

Ariefa Efianingrum dan Mami Hajaroh, Kebijakan Pencegahan Kekerasan terhadap Anak di Sekolah Dasar, Prosiding Riset Kebijakan Pendidikan Anak di Indonesia, kerjasama antara Kemendikbud, UNICEF Indonesia, Lembaga Penelitian SMERU, 2012.

Enggal Wildan Prabowo, Ishartono dan Meilanny Budiarti, Pola Asuh Anak Oleh Ibu

Usia Dini, PROSIDING KS: RISET \& PKM, Volume 2, Nomor 2, ISSN: 2442-4480.

Enjang Wahyuningrum, Peran Ayah (fathering) pada Pengasuhan Anak Usia Dini,

Fakultas Psikologi Universitas Kristen Satya Wacana.

Esya Anesty Mashudi dan Nur'aini, Pencegahan Kekerasan Seksual Pada Anak

Melalui Pengajaran Personal Safety Skills, Metodik Didaktik, Volume 9, Nomor. 2, Januari 2015.

Ismantoro Dwi Yuwono, Penerapan Hukum dalam Kasus Kekerasan Seksual terhadap Anak, Pustaka Yustisia, Yogyakarta, 2015.

Ivo Noviana, Kekerasan Seksual Terhadap Anak: Dampak dan Penanganannya, Sosio Informa, Volume 1, Nomor 1, Januari-April, Tahun 2015.

Joko Tri Suharsono, Aris Fitriyan, dan Arif Setyo Upoyo, Hubungan Pola Asuh Orang

Tua terhadap Kemampuan Sosialisasi Pada Anak Prasekolah di TK Pertiwi Purwokerto Utara, Jurnal Keperawatan Soedirman (The Soedirman Journal of Nursing), Volume 4, Nomor 3, November 2009.

M. Anwar Fuadi, Dinamika Psikologi Kekerasan Seksual: Studi Fenomenologi, PSIKOISLAMIKA, Jurnal Psikologi Islam (JPI), Volume 8, Nomor 2, Januari 2011.

Nur Hidayati, Perlindungan Anak terhadap Kejahatan Kekerasan Seksual (Pedofilia),

Ragam Jurnal Pengembangan Humaniora, Volume 14, Nomor 1, April 2014.

Syifa Khoirunnisa, Nita Fitria, Helwiyah Rofi, Gambaran Pola Asuh Orang Tua Yang Dipersepsikan Remaja Sma Negeri Jatinangor Kabupaten Sumedang, Jurnal IImu Keperawatan. Volume III, No. 2, September 2015.

Vina Kartikasari, Tinjauan Yuridis Tentang Urgensi Perlindungan Hukum Terhadap Anak Sebagai Korban Tindak Pidana Perkosaan, Skripsi, Universitas Brawijaya, 2013.

Yanuar Farida Wismayanti, "Perdagangan Anak Perempuan yang Dilacurkan: Potret 
Suram Kemiskinan Versus Perlindungan Anak/Female Child Sex Trafficking: Gloomy Portrayal of Poverty Versus Child Protection", Prosiding, 2013.

\section{Dokumen Hukum}

Undang-Undang Dasar Negara Republik Indonesia 1945.

Undang-Undang Nomor 4 Tahun 1979 tentang Kesejahteraan Anak.

Undang-Undang Nomor 39 Tahun 1999 tentang Hak Asasi Manusia.

Undang-Undang Nomor 23 Tahun 2002 tentang Perlindungan Anak.

Undang-Undang Nomor 35 Tahun 2014 tentang Perubahan atas Undang-Undang Nomor 23 Tahun 2002 tentang Perlindungan Anak. 